\title{
The Effect of Transformational Leadership and Organizational Culture Towards Employees' Innovative Behaviour and Performance
}

\author{
Submitted $28 / 2 / 18,1^{\text {st }}$ revision $10 / 3 / 18,2^{\text {nd }}$ revision $14 / 5 / 18,3^{\text {rd }}$ revision $21 / 12 / 18$, \\ accepted $1 / 3 / 19$
}

\section{Mochamad Rizki ${ }^{1}$, Ryani Dhyan Parashakti ${ }^{2}$, Lisnatiawati Saragih ${ }^{3}$}

\begin{abstract}
:
This study aims to analyse the effect of Transformational Leadership and Organizational Culture towards Innovative Behaviour and Employee Performance in PT Bank Danamon Indonesia.

Data was collected from a sample of 100 employees of PT Bank Danamon Indonesia. We analysed the questionnaire result using structural equation modelling (SEM).

The conclusions are that transformational leadership has a significant effect on organization culture; transformational leadership does not influence innovation behaviour.

However, a company's culture is significantly affected by innovation behaviour and innovation behaviour also has a significant effect on employee performance in PT Bank Danamon Indonesia.

Transformational leadership is concerned with shared interests among employees by explaining the importance of the company's goals so that employees are willing to put aside their personal interests and work for the common good.
\end{abstract}

Keywords: Transformational leadership, organizational culture, innovative behaviour, employee's performance.

\footnotetext{
${ }^{1}$ Management Studies Program, Economics and Business Faculty, Mercubuana University, Jakarta, Indonesia, E-mail: mochrzk@gmail.com

${ }^{2}$ Management Studies Program, Economics and Business Faculty, Mercubuana University, Jakarta, Indonesia

${ }^{3}$ Management Studies Program, Economics and Business Faculty, Mercubuana University, Jakarta, Indonesia
} 


\section{Introduction}

PT. Bank Danamon has been at the forefront of investing their capital resources heavily for the advancement of technology. Being technologically advanced allows employees to be more innovative. Innovation is the process of making changes from something that already exists with the introduction of something new (O'Sullivan, 2007). Innovation can be included in the company's procedures, policies and regulation. Innovation would form part of the procedures that employees would follow unconsciously.

Innovative behavior of employees in PT Bank Danamon Indonesia is reflected from the procedures, policies, and regulations of the company. Many of the procedures, policies, and regulations of the company are in fact already over 10 years old and have not been revised recently. Procedures, policies and regulations of the company are a benchmark in the company's innovative behavior because with these, one can see the ideas flowing and being implemented in the company. If the procedures, policies and regulations that exist in the company have not been updated for a long period of time, this indicates that people in the company are likely to feel stagnated and not up to date.

Innovation in the organization cannot be separated from the role of leaders in the organization. The style of leadership is very influential in fostering innovative behavior of employees. Leaders in PT Bank Danamon Indonesia (except the President Director) are almost all employees who have a very long service life, more than 20 years. Seniority counts in PT Bank Danamon Indonesia. The Company highly appreciates employees who have worked for a long time and they are rewarded in the form of managerial positions where they must manage a team.

Table 1. Employment Period

\begin{tabular}{lllll}
\hline \multirow{2}{*}{ No. } & \multirow{2}{*}{ Years of service } & \multicolumn{2}{c}{ Quantity } & \multirow{2}{*}{ Total } \\
\cline { 3 - 4 } & & Man & Woman & \\
\hline 1 & $0-3$ months & 6 & & 6 \\
2 & $>3$ months -1 year & 21 & 7 & 28 \\
3 & $>1-3$ years & 32 & 9 & 41 \\
4 & $>3-6$ years & 31 & 4 & 35 \\
5 & $>6-9$ years & 28 & 16 & 44 \\
6 & $>9-12$ years & 10 & 4 & 14 \\
7 & $>12-15$ years & 2 & 2 & 4 \\
8 & $>15-18$ years & 18 & 3 & 21 \\
9 & $>18-21$ years & 16 & 3 & 19 \\
10 & $>21-24$ years & 15 & 1 & 16 \\
11 & $>24$ years & & 1 & 1
\end{tabular}


TOTAL

179

50

229

Source: Personnel Data of PT Bank Danamon Indonesia Indonesia (2015).

It can be noted from the employment period table above (Table 1) that there are a lot of employees who have worked at the bank for more than 10 years. Some of those already occupy a managerial position (Senior Manager until General Manager). Indeed, they have very strong technical capabilities, but lack of leadership skills. The company seems to neglect to provide leadership skills for them. The absence of leadership skills leads to team not performing well. They may have a different leadership style from one another. Leaders usually have transactional leadership style; followers are motivated through a system of rewards and punishments, as stated by Bass in Yuki (2010), however there are also those who have a transformational leadership style.

Transformational leaders expect subordinates to challenge the status quo and try new approaches that are better in their lives (Wang \& Rode, 2011). They also highlight the contributions of subordinate to the organization, to motivate subordinates to develop and offer more ideas towards the organization's success (Wang \& Rode, 2011). Table 1 shows the employment service period in PT Bank Danamon. Since seniority is an important factor in managing the company, the authors concluded that the company's organizational culture is the culture with clan domination. Cameron $\&$ Quinn, (2006) state that most Japanese companies are dominant on clan culture and the cultural characteristics of this clan is holding steadfast loyalty and tradition.

Innovation is the process of making changes from something that already exists with the introduction of something new (O'Sullivan, 2007). In this regard, the bank has created new products in order to compete with its competitors. One of the innovative products that have been produced by PT Bank Danamon is the Danamon's electronic banking system prioritizing more on saving administrative and transfer costs. Employee performance is measured through job performance according to specific targets set by the company in a certain period. According to Armstrong (2009), performance covers both what has been achieved and how it has been achieved.

Overseeing employee performance helps allocate organization's strategy, policy and practices with regard to establishing superior performance along with measuring and monitoring the result. A comprehensive execution administration framework can play a vital part in pulling in and holding key workers. It too can help in the progress of a company's general business execution. Based on the description stated previously, the problem of this study can be formulated as follows:

(1) Does transformational leadership have a significant effect on organization culture?

(2) Does Transformational leadership influence innovation behavior?

(3) Does a company's culture significantly affected innovation behaviour 
(4) Does innovation behaviour have a significant effect on employee performance?

\section{Definition of Terms}

\section{a. Transformational Leadership}

Leadership is the ability to influence a group of people to achieve a goal (Robbins \& Judge, 2013). Sources of these influences can be formal or informal, as the top leaders provide managerial strength to someone. Leadership appears when subordinates (followers) are influenced to do what is ethical and beneficial to the organization and for themselves (Achua \& Lussier, 2010). Organizations need a strong leader and a strong management to ensure the effectiveness of the organization (Robbins \& Judge, 2013). According to Yuki (2010), leadership is the process of giving purpose (meaningful direction) to collective effort, which leads to the effort expended to achieve the goal. According to Ritawati (2013), leadership is one of the critical success factors of the organization. A leader is a person who moves early, goes ahead, takes the first step, does the first, pioneering, direct action, minds the opinion of others, guides, leads, and mobilizes others through influence. Situational approach realized there is no single best leadership style that is universally applicable to all situations and environments (Ritawati, 2013).

A leader can choose the type of leadership style appropriate to the objectives pursued by leaders in the organization he leads. There are several types of leadership, each having their own character, such as an attribution leader, a concept which suggests that the leader is solely an attribution made by people for other individuals. There is also the charismatic leader whose followers make attributions of the leader's heroic or extraordinary ability. Transformational leadership is lately being more talked about and it is the type of leadership that is one of the variables in this study.

Transformational leadership is an attempt to motivate the employees to work in order to achieve organizational objectives and satisfying their needs at a higher level. Putra \& Subudi (2015) saw that if transformational leadership can be applied properly by the company, it will provide motivation for employees, in order to achieve a sense of satisfaction in their work, and that all this will have a positive effect on the performance of employees in taking responsibility for the company's interests. Transformational leader inspires subordinates to further enhance their interests for the good of the organization and has a tremendous influence on subordinates (Robbins \& Judge, 2013).

\section{b. Organizational Culture}

Stanislavov and Ivanov (2014) tried to bring the culture of the organization to align with the strategy; therefore, they explained the concept of "The Cultural Web" to map the organizational culture. An organizational culture is where assumptions and behaviours in the organizations break down into six elements: stories, symbols, 
rituals and routines, control systems, power structures and organizational structure. The basic assumption has proved to be applied properly to resolve the problems encountered and considered valid. Therefore, it is taught to new members as the correct way to perceive, think and have a strong understanding in relation to these problems. Culture in an organization has a big influence on the personal formation that is within the organization. That is, if the organizational culture does not support the growth of creative people in the organization, then certainly the creativity of people will be frozen and most likely difficult to be developed if they were no longer in the organization.

In 2006, Cameron and Quinn formulate the Organizational Culture Assessment Instrument (OCAI) to assess the organizational culture by using a questionnaire. OCAI is a questionnaire instrument of Competing Values Framework (CVF). CVF was originally created as a criterion for the effectiveness of the organization consisting of three dimensions. The first dimension, the horizontal line, split the focus of the organization by comparing the internal and external orientation. The second dimension, the vertical line, consists of the choice of organization between the stability and control compared with the flexibility and change. The third dimension is comparing the process with the result. However, OCAI does not use this third dimension and therefore OCAI only has two dimensions: internal vs. external and flexibility vs. stability (Cameron \& Quinn, 2006).

OCAI divides the two dimensions into four quadrants. Cameron and Quinn (2006) named each quadrant as clan, adhocracy, market and hierarchy. Hierarchy Culture focuses on formal coordination, decision-making and centralized authority. This culture emphasizes stability. Hard, accuracy, unchanged, neat and clean can be used to describe this hierarchical culture. Market Culture emphasizes productivity, efficiency, measurable results and a clear goal. Adhocracy Culture emphasizes growth, innovation, flexibility, risk taking, commitment and modernity. Adhocracy is creating a workplace culture that is creative, dynamic and nuanced for entrepreneurs. Individual initiative and freedom are being respected. Clan Culture, sometimes also called the culture of the group, is a pleasant place where people can share a lot. Broad participation, teamwork, consensus, decentralized decisionmaking and loyalty are part of this clan culture.

\section{c. Innovative Behaviour}

The process of innovation in a job could be created from the new idea itself or acquired from employees or business partners, friends and managers. Then there is a process to communicate these ideas to others. If the idea can be implemented and approved, the preparatory phase of implementation can be done.

Although scientists and practitioners emphasize the importance of innovative behaviour at work (innovative work behaviour / IWB), a measurement of innovative behaviour is still very difficult to do. De Jong and Hartog (2008) provide four (4) 
dimensions for the measurement of innovative behaviour in the workplace (IWB), namely: opportunity exploration, idea generation, championing and application.

Innovation theory often stresses that innovation is more spacious than the creativity and inside it is included the implementation of the ideas created. Therefore, De Jong and Hartog (2008) developed an IWB which not only describes the problem of how to generate ideas, but also the behaviour required for the implementation of those ideas that can improve the performance of individuals and organizations. De Jong \& Hartog (2008) define the innovative behaviour in the workplace / Innovative Work Behavior (IWB) as an individual behaviour that aims to reach the stage of introduction or attempt to introduce (in his work, group or organization) ideas, processes, products or new and useful procedures. Therefore, the IWB measurement that they developed includes both stages of the introduction and implementation of creative ideas.

The beginning of the innovation process is often determined by chance: find an opportunity, problems that arise or puzzles that need to be solved. Exploring opportunities include finding ways to improve the service or the latest delivery process or try to think of the work process, product or service in an alternative way. Idea generation is the next element of the IWB and constitutes the first step in exploiting the opportunities. To be able to innovate, in addition to knowing one's chances/opportunities, there needs to be the ability to develop new ways to take advantage of opportunities that is also important. Idea generation refers to the drafting for the purpose of improvement. The ideas generated can be associated with a product, service or process, entry into new markets, an increase in the work process at this time, or in general is the solution to the problems that have been identified.

Championing is another important aspect when an idea is generated. Most of the ideas need to be sold. Coalitions are often needed to implement innovations; this is how one gets the power to sell the idea to potential partners. In many cases, the prospective users of the proposed innovation (colleagues, leaders, customers, etc.) often do not feel confident with the added value of these innovations. This requires expertise to be able to sell and convince the buyer. This stage is called championing, trying to convince the added value of the innovation that is proposed.

Furthermore, the ideas that have been supported need to be implemented and practised. Implementation means improving the product or procedure that is there or building a new one. Hard effort and a result-oriented attitude are required from employees to embody the idea. Behaviour needs to turn into action by the individual to be able to put that idea into practice.

\section{d. Employee Performance}

Performance can be traced back to the behaviour of people on the shop floor. Employees work in a certain way or behave in a way that contributes to (the goals 
of) the organisation Viswesvaran and Ones (2000). Employees' behaviour in relation to organisational performance can manifest itself in three different ways (Dunlop and Lee, 2004). According to Armstrong (2009), there are three factors that affect the level of individual performance: motivation, ability and opportunity to participate. Performance is derived from the word job performance or actual performance which means work performance or achievement achieved by someone. Understanding the performance (work performance) is the work of quality and quantity achieved by an employee in performing his functions in accordance with the responsibilities given to him. Performance is the result or level of success of a person during a certain period in carrying out the task. The task comprises of various attributes, such as standards of work, targets or predetermined criteria which have been previously set and agreed upon.

\section{Framework and Hypothesis}

Based on the problem formulation and basic theories that have been described before, the hypotheses in this study are as follows:

$H_{1}$ : Transformational leadership has a significant effect on the organisation culture of PT Bank Danamon Indonesia.

$\mathrm{H}_{2}$ : Transformational leadership has a significant effect on the innovative behaviour of PT Bank Danamon Indonesia.

$\mathrm{H}_{3}$ : Organizational culture has significant effect on the innovative behaviour of PT Bank Danamon Indonesia.

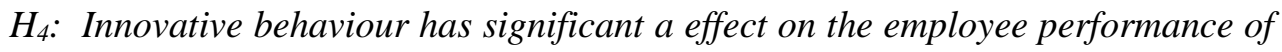
PT Bank Danamon Indonesia.

\section{Research Methodology}

Data were taken from a questionnaire distributed to employees of PT Bank Danamon Indonesia by using a random sampling technique selecting a total sample of 100 people from a total population of 229 employees.

Analysis of the data is an activity to classify, create a sequence, manipulate, and sort data, making it easy to read and understand (Hair et al., 2010). The method chosen for data analysis must be in accordance with the pattern of research and variables to be studied. The model used in this study is a model of causality or influence relationships. To test the hypothesis proposed in this study, the technique of analysis used is Structural Equation Modelling (SEM) operated by AMOS 21. Modelling studies through SEM allows researchers to answer research questions that are dimensional (i.e. measure the indicators of a concept) and regressional (the measure of influence or degree of relationship between the factors identified). Ferdinand (2006) states several reasons for the use of the SEM program as an analytical tool due its compatibility for: (1) Confirming non-dimension of various indicators to a dimension/construct/concept/factor; (2) Testing suitability/provision of a model 
based on empirical data studied; (3) Examining the suitability of the model as well as the causality relationship between the factors constructed/observed in the research model.

This study used confirmatory factor analysis. Confirmatory factor analysis in the SEM is used to confirm the factors predominant in one group of variables. In this study, a confirmatory factor analysis was used to test the indicators that make up the transformational leadership, organizational culture, organizational innovation and employee performance.

\section{Result and Discussion}

\section{A. Validity}

To test the validity of variables and indicators, the authors use the value of $r$. The value of $r$ is calculated and compared with the $r$-table; the results obtained from the calculation of the variables and indicators in this study show that these are valid. When the validity test is done, we move to the next test which is the reliability test.

\section{B. Reliability}

Arikunto (2006) states that "Reliability refers to a sense that the instruments are trustworthy enough to be used as a means of collecting data as the instrument is good". Questionnaires are said to be reliable if they can provide relatively similar results (steady) during the measurement of return on different objects at different times or give consistent results. Reliability tests were performed with Cronbach alpha formula. If the Cronbach Alpha coefficients are higher than 0.7, then the instrument is reliable (Johnson \& Christensen, 2012).

Table 3. Reliability Test

\begin{tabular}{lll}
\hline Variables & Cronbach Alpha & N of Items \\
\hline Transformational leadership & 0.919 & 5 \\
Organizational culture & 0.822 & 4 \\
Innovative behaviour & 0.868 & 4 \\
Performance & 0.844 & 3 \\
\hline
\end{tabular}

Table 3 above shows the Cronbach Alpha coefficients. All values are higher than 0.7 , therefore it is confirmed that all variables are reliable.

\section{Model test measurement}

Model test measurement is used to examine the relationship between indicators of the latent variable. The measurement test results obtained a Chi-square of 351.182, the degree of freedom is 93 and a probability level of 0.00 . 
Figure 1. Structural test model

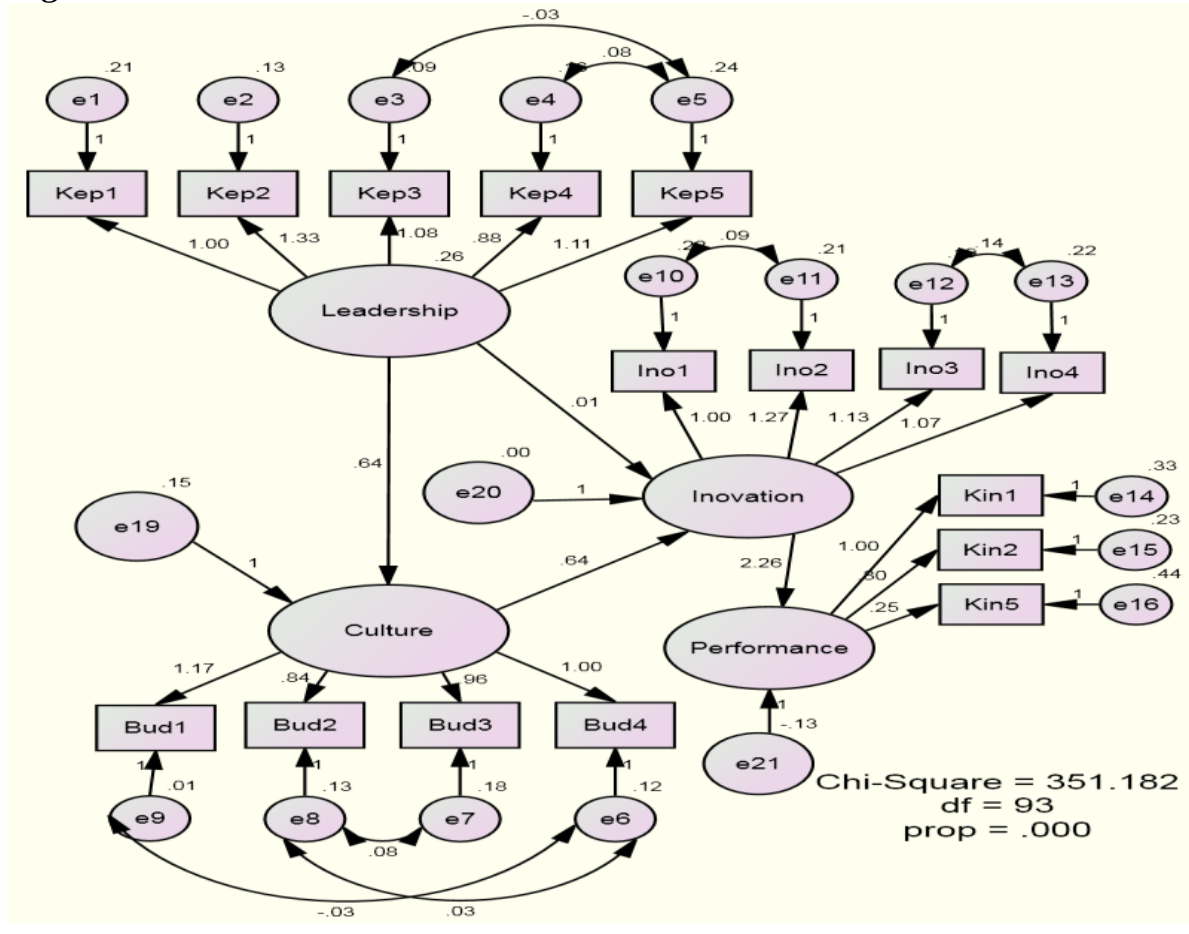

D. Normality Test

The Skewness critical value of \pm 2.58 is used to evaluate normality at the 0.01 level (1\%). Data is said to be normally distributed if the value of skewness critical ratio value is between \pm 2.58 (Ferdinand, 2006). After we tested, the results show all variables are normal.

\section{E. Goodness of Fit Model}

The model is feasible if at least one test from the above is met (Hair et al., 2010). In an empirical study, the researchers are not required to meet all the criteria of goodness of fit, however, this depends on the judgment of each researcher. ChiSquare value in this study was 351.182. Hair et al. (2010) say that the Chi-Square cannot be used as the sole measure of overall suitability of the model, because the Chi-Square value does not indicate a good fit model. Table 5 is a criterion test for suitability model where most of the results are poor.

Table 5. Goodness of Fit Model

\begin{tabular}{lllll}
\hline No & Index & Critical value & result & $\begin{array}{l}\text { Evaluation } \\
\text { Model }\end{array}$ \\
\hline 1 & Chi-Square & close to zero & 351.182 & Poor \\
2 & probability level & $\geq 0.05$ & 0.000 & Poor \\
3 & CMIN / DF & $<5.00$ & 4.838 & Good
\end{tabular}




\begin{tabular}{lllll}
\hline & & & & \\
5 & CFI & $\geq 0.90$ & 0.735 & Poor \\
6 & RMSEA & $\leq 0.08$ & 0.197 & Poor \\
6 & TLI & $\geq 0.90$ & 0.682 & Poor \\
7 & GFI & $\geq 0.90$ & 0.679 & Poor \\
8 & AGFI & $\geq 0.90$ & 0.563 & Poor \\
\hline
\end{tabular}

\section{F. Modification Model}

Since the model has many bad results, we modified the model according to modification indices given by the program.

Table 6. Goodness of Fit Model After Modification

\begin{tabular}{lllll}
\hline No. & Index & Critical value & Result & $\begin{array}{l}\text { evaluation } \\
\text { Model }\end{array}$ \\
\hline 1 & Chi-Square & close to zero & 351.182 & Poor \\
2 & probability level & $\geq 0.05$ & 0.00 & \\
3 & CMIN / DF & $<5.00$ & 3.776 & Good \\
4 & CFI & $\geq 0.90$ & 0.822 & Marginal \\
5 & RMSEA & $\leq 0.08$ & 0.167 & Fair \\
6 & TLI & $\geq 0.90$ & 0.770 & Fair \\
7 & GFI & $\geq 0.90$ & 0.710 & Fair \\
8 & AGFI & $\geq 0.90$ & 0.576 & Poor \\
\hline
\end{tabular}

Table 6 shows that the default value of four models measuring TLI, CFI, GFI and RMSEA are fair, indicating that the model is fit. It can be stated that this test produces a marginal confirmation of the dimensions of the factors and causal relationships between variables.

\section{G. Causality Test}

Causality test aims to determine the causal relationship between exogenous and endogenous variables in a study. In addition, this is used to test the hypothesis formulation that had been submitted in the methodology of the study. The test results regression weight can be seen in Table 7 .

Table 7. Causality Test

\begin{tabular}{|c|c|c|c|c|c|c|}
\hline & & & S.E. & C.R. & $\mathrm{P}$ & Result \\
\hline Culture & $<-$ & Leadership & .110 & 5.818 & $* *$ & Supported \\
\hline Innovation & $<-$ & Leadership & .027 & .209 & .834 & Not Supported \\
\hline Innovation & $<--$ & Culture & .107 & 5.993 & $* *$ & Supported \\
\hline Performance & $<--$ & Innovation & .359 & 6.299 & $* *$ & Supported \\
\hline
\end{tabular}

The results of the causality test showed the P-Value for Leadership to Innovation is higher than 0.05 , meaning there is no effect of Leadership on Innovation. The rest of the values are positively affected. Effects of each independent variable on the dependent variable can be explained as follows. 


\section{H. Hypothesis Findings and Discussion}

To investigate the effect between the independent variable leadership and the dependent variables like the company's culture, innovation behaviour and employee performance, these were tested by comparing probability values from each hypothesis with a cut off value of 0.05 .

The first hypothesis is to find out the influence of transformational leadership on organizational culture. The test showed there is an influence of transformational leadership on organizational culture. This means that the leadership role inspires subordinates to perform well and creates a positive company culture in achieving its goal. Good leadership might be achieved through coaching and mentoring subordinates into timely action, take the first step, be pioneering work, mind the opinion of others, guide, lead, and mobilize others through influence.

The second hypothesis is to find out the influence of transformational leadership on innovation behaviour. The test result shows transformational leadership does not influence innovative behaviour. Theoretically, innovation should be mobilized by the leader. Most companies in Indonesia have been practising the seniority concept in their management hierarchy. They think that older persons with a long period of working experience have knowledge and expertise which are higher than those of younger employees. Older persons believe that their experience can solve problems in the company. They avoid innovation and think innovation is slowing down the operation. PT. Bank Danamon also appoints older persons who have a lot of experiences to fill the higher ranks in management. Table 1 shows that 16 employees have been working for more than 20 years. This situation might be the cause that transformational leadership does not affect innovation behaviour.

The third hypothesis is the effect of organizational cultures on innovation behaviour. From the tests conducted, the result of this hypothesis is below the cut-off point which is 0.05. It means there is an effect between organizational culture and innovation behaviour. The culture at PT. Bank Danamon encourage employees to innovate in order to compete with other banks. The employee is given the opportunity to innovate to improve the management process or to create banking products which can be sold to customers. There are many innovative banking products created by PT Bank Danamon, for example, arranging interest loans for housing and goods.

The fourth hypothesis is to find out the influence of innovation behaviour on employee performance. According to the test, there is an influence of innovation behaviour on employee performance. Therefore, innovative companies should promote employees to be innovative in order to maximize the effect of innovative performance on organizational performance. 
Transformational leadership is concerned with explaining the importance of the company's objectives so that members are willing to put aside their personal interests in order to achieve the company's objectives:

$\checkmark$ PT. Bank Danamon should apply transformational leadership to motivate employees to see beyond their personal interests. Leaders must be able to translate the mission and vision of the organization and maximise energy resources, both human and instrumental in pursuing the company's overall goals.

$\checkmark$ PT. Bank Danamon should provide training for leaders to understand further transformational leadership. Proper training will make leaders reach their full potential.

$\checkmark \quad$ The leaders of the Bank who already have training should develop and act professionally and in a disciplined manner, seeking cooperation and caring (values Danamon) in everyday applications so that transformational leadership can have a positive influence on employees.

$\checkmark$ PT. Bank Danamaon should consider promoting younger employees to higher ranks of management. Youngsters have many innovative and creative ideas in their mind which would make PT. Bank Danamon a bank with a lot of innovations emerges.

\section{References:}

Achua, C.F. and Lussier, R.N. 2010. Effective Leadership, 4th Edition, Canada, SouthWestern.

Arikunto, S. 2006. Research Procedure: A Practice Approach. Jakarta: Rineka Cipta.

Armstrong, M. 2009. A Handbook of Human Resource Management Practice, 10th ed. London.

Cameron, K.S. and Quinn, R.E. 2006. Diagnosing and Changing Organizational Culture. John Wiley \& Sons, Inc. US.

De Jong, J.P.J., Hartog, D.N. 2008. Innovative Work Behavior: Measurement and Validation. SCALES, Zoetermeer.

Dunlop, P.D. and Lee, K. 2004. Workplace Deviance, Organizational Citizenship Behavior and Business Unit Performance: The Bad Apples do spoil the whole Barrel. Journal of Organizational Behavior, 25, 67-80.

Ferdinand, A. 2006. Structural Equation Modeling (SEM) in Management Research. Management Master's Degree Program of Dipenogor University. Semarang.

Hair, J.F., Anderson, R.E., Tatham, R.L. and Black, C.W. 2010. Multivariate Data Analysis, Seventh Edition. Pearson, New Jersey.

Johnson, B., Christensen, L. 2012. Educational Research, 4th ed. Los Angeles, CA: Sage.

O'Sullivan, D. 2007. Applying Innovation in Information Systems Management at IngersollRand Corporation. In T. Dundon and A. Wilkinson (eds). Case Studies in People Management, Strategy and Innovation. Australia: Tide University Press.

Putra, I., Subudi, M. 2015. Influence of Transformational Leadership Style and Physical Work Environment on Employee Performance of PT BPR Pedungan. E-Journal Management, 4(10), 3146-3171. 
Ritawati, A. 2013. The Effect of Transformational Leadership and Organizational Culture on Job Satisfaction and Employee Performance of PT. Jamsostek (Persero) Surabaya Branch. Journal of Economics \& Management, 9(1), 82-93.

Robbins, S.P. \& Judge, T.A. 2013. Organizational Behavior, Fifteenth edition. Prentice Hall, New Jersey.

Stanislavov, I., Ivanov, S. 2014. The Role of Leadership for Shaping Organizational Culture and Building Employee Engagement in the Bulgarian Gaming Industry. Original Scientific Paper, Vol. 62, No. 1, 19-40.

Viswesvaran, C. and Ones, D.S. 2000. Perspectives on Models of Job Performance. International Journal of Selection and Assessment, 8, 216-226.

Wang, P., Rode, J.C. 2011. Transformational Leadership and Follower Creativity: The Moderating Effects of Identification with Leader and Organizational Climate. Sagepub. Ohio.

Yuki, G. 2010. Leadership in Organization, Fifth edition. Index, Jakarta. 